\title{
The relation of $B C G$ vaccination and severe malnutrition with the occurrence of tuberculous meningitis
}

\author{
Nofareni, MD; Bistok Saing, MD; Ridwan M. Daulay, MD; Bidasari Lubis, MD
}

\begin{abstract}
Objectives To assess BCG vaccination and nutritional states in children with tuberculous meningitis and their relations with the occurrence of tuberculous meningitis.

Methods A case-control study was conducted at the Division of Neurology, Department of Child Health, Adam Malik Hospital, Medan, from January 1997 to December 2000. Subjects of this study were all tuberculous meningitis patients and primary tuberculosis patients as the control group. Odds ratio (OR) was used to assess the risk of tuberculous meningitis in patients with positive BCG vaccination and (1-OR) was used to assess the efficacy of BCG to prevent tuberculous meningitis.

Results Four out of sixteen tuberculous meningitis patients were vaccinated, while 10 of 16 primary tuberculosis patients were vaccinated $(p=0.03)$. OR of vaccinated patients to get tuberculous meningitis was $0.2(95 \% \mathrm{Cl} 0.04 ; 0.91)$. The efficacy of BCG vaccination to prevent tuberculous meningitis was $1-0.2=0.8$. The risk of severe malnourished patients to get tuberculous meningitis was 2.33 (95\% Cl 0.52;10.48; $p=0.26)$.
\end{abstract}

Conclusion Most tuberculous meningitis patients were not BCG vaccinated. Severe malnutrition did not play role in the occurrence of this disease [Paediatr Indones 2004;44:12-16].

Keywords: $B C G$ vaccination, tuberculous meningitis, primary tuberculosis, severe malnutrition

T uberculous meningitis (TBM), an inflammation of the meninges, is one of the complications of primary tuberculosis. Mostly, the primary site of infection is the lung. ${ }^{1}$ The incidence of TBM is 1 of 300 primary tuberculosis patients who were not treated. ${ }^{2}$ It has a high morbidity, mortality, and poor prognosis. The incidence of TBM varies based on socioeconomic state, age, nutritional status, and genetic factors that influence the immunologic response. ${ }^{1,3}$ Bacille Calmette-Guerin (BCG) vaccination is one method to prevent tuberculosis by improving immunity. 2,4 The efficacy of BCG vaccination in preventing primary tuberculosis varies from 0 to $80 \% .^{6}$ In a case-control study in Jakarta, Putrali et al reported the efficacy of BCG vaccination in preventing all types of tuberculosis was $34 \%$. ${ }^{7}$

TBM is one of the severe complications of primary tuberculosis that occurs by hematogenous spread. ${ }^{1}$ The immunity provided by BCG has a role in preventing hematogenous spread but not for direct or lymphogenous spread. ${ }^{5}$ The Ministry of Health Republic of Indonesia reported that the coverage of BCG vaccination in 1996/1997 was $99.6 \%{ }^{8}$ Theoretically, TBM should have been prevented, because basic vaccination program, especially BCG, was successful.

This study aimed to assess the relation of BCG vaccination and nutritional status with the occurrence of tuberculous meningitis.

From the Department of Child Health, Medical School, University of Sumatera Utara, Medan, North Sumatera, Indonesia

Reprint requests to: Nofareni, MD, Department of Child Health, Medical School, University of Sumatera Utara, Medan, North Sumatera, Indonesia. Tel/Fax. 061-8361721 
Nofareni, $\mathrm{MD}$ et al: BCG vaccination, severe malnutrition, and tuberculous meningitis

\section{Methods}

This was a case-control study conducted on all patients who were diagnosed as having TBM in the Division of Neurology, Department of Child Health, Adam Malik Hospital, from January 1997 to December 2000. Data were obtained from medical records including age, sex, body weight and height, nutritional status, history of contact with tuberculous adult, and BCG vaccination status. The primary tuberculosis patients were diagnosed in the Division of Pulmonology, Department of Child Health, Adam Malik Hospital and assigned as the control group. The inclusion criterion was all patients with known BCG vaccination status. Patients suffered from severe extrapulmonary tuberculosis were excluded.

TBM patient was defined as a patient with clinical manifestations of meningitis and showed abnormalities of cerebrospinal fluid, including pleocytosis

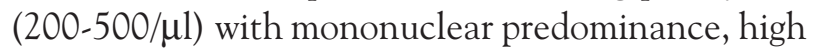
protein concentration, and low glucose concentration less than half of blood glucose level performed at the same time. ${ }^{1,2,9}$ Primary tuberculosis was diagnosed based on clinical findings, history of contact to tuberculous adult, result of Mantoux test, and chest $\mathrm{x}$-ray. ${ }^{10}$ Positive $\mathrm{BCG}$ vaccination status was defined based on history of vaccination and BCG scar on right deltoid. ${ }^{11,12}$ The scar was described as a round, slightly depressed area with irregular edges, $4-7 \mathrm{~mm}$ in diameter. ${ }^{12}$ Close contact was defined as sharing a same household or other enclosed environments with adults known or suspected to have tuberculosis. ${ }^{13}$ Severe malnutrition was classified according to WHO-NCHS and Semiloka Antropometri Indonesia 1991 i.e., body weight of less than $-3 \mathrm{SD}$ according to body length. ${ }^{14}$

The risk of TBM in patients with positive BCG vaccination status and severe malnutrition were calculated by OR. The efficacy of BCG to prevent TBM was calculated by $1-O R$. Statistical significance was accepted with confidence level of $95 \%(\mathrm{p}<0.05)$. Data were processed with SPSS 10.0 for Windows.

\section{Results}

During four years of the study, we found 37 TBM and 41 primary tuberculosis patients. Five of thirty-seven
TBM patients were excluded due to unknown BCG vaccination status. Nine of forty-one primary tuberculosis patients were excluded because 6 patients did not have clear BCG vaccination status and 3 patients suffered from severe extra-pulmonary complications. Furthermore, we analyzed only thirtytwo patients in two groups, because 16 in each group were matched.

Table 1 shows the characteristics of patients in each group including the distributions of sex, age, body weight, and history of contact with tuberculous adult, which were not significantly different between TBM and primary tuberculosis $(p=0.71,0.19,0.72$, and 0.67 respectively). Table 2 shows the role of BCG vaccination status in the occurrence of TBM. Four out of sixteen TBM patients were vaccinated, whereas 10 of 16 primary tuberculosis patients were vaccinated $(p=0.03)$. The vaccinated patients had a risk to suffer from TBM 0.2 (95\%CI 0.04;0.91), so that efficacy of BCG to prevent TBM is $1-0.2=0.8(95 \% \mathrm{CI}$ 0.09;0.96). Table 3 shows that most TBM patients also suffered from severe malnutrition but this was not statistically significant $(p=0.26)$. The risk of severe malnourished children to suffer from TBM was $2.33(95 \% \mathrm{CI} 0.52 ; 10.48)$.

Table 1. Characteristics of tuberculous meningitis AND PRIMARY TUBERCULOSIS PATIENTS

\begin{tabular}{|c|c|c|}
\hline Characteristics & $\begin{array}{l}\text { Tuberculous } \\
\text { meningitis }\end{array}$ & $\begin{array}{l}\text { Primary } \\
\text { tuberculosis }\end{array}$ \\
\hline \multicolumn{2}{|l|}{ Sex } & 16 \\
\hline Male & 10 & 11 \\
\hline Female & 6 & 5 \\
\hline \multicolumn{3}{|l|}{ History of contact } \\
\hline Positive & 12 & 13 \\
\hline Negative & 4 & 3 \\
\hline \multicolumn{3}{|l|}{ Body weight $(\mathrm{kg})$} \\
\hline Mean (SD) & $9.6(3.5)$ & $11.5(4.4)$ \\
\hline \multicolumn{3}{|l|}{ Age (months) } \\
\hline Mean (SD) & $36(29)$ & $32(27)$ \\
\hline
\end{tabular}

Table 2. The role of BCG Vaccination in the OCCURRENCE OF TUBERCULOUS MENINGITIS

\begin{tabular}{|c|c|c|c|}
\hline BCG vaccination & $\begin{array}{l}\text { Tuberculous } \\
\text { meningitis }\end{array}$ & $\begin{array}{l}\text { Primary } \\
\text { tuberculosis }\end{array}$ & Total \\
\hline Yes & 4 & 10 & 14 \\
\hline No & 12 & 6 & 18 \\
\hline Total & 16 & 16 & 32 \\
\hline$X^{2}=4.57$ & $0.03 \quad \mathrm{OR}=0.2$ & $(95 \% \mathrm{Cl} 0.04 ; \mathrm{C}$ & 1) \\
\hline
\end{tabular}


Table 3. The role of SeVere malnutrition IN the OCCURRENCE OF TUBERCULOUS MENINGITIS

\begin{tabular}{lccc}
\hline $\begin{array}{l}\text { Severe } \\
\text { malnutrition }\end{array}$ & $\begin{array}{l}\text { Tuberculous } \\
\text { meningitis }\end{array}$ & $\begin{array}{l}\text { Primary } \\
\text { tuberculosis }\end{array}$ & Total \\
\hline Yes & 7 & 4 & 11 \\
No & 9 & 12 & 21 \\
\hline Total & $\mathbf{1 6}$ & $\mathbf{1 6}$ & $\mathbf{3 2}$ \\
\hline $\mathrm{X}^{2}=1.25 \quad \mathrm{df}=1$ & $p=0.26 \quad \mathrm{OR}=2.33$ & $(95 \% \mathrm{Cl} 0.52 ; 10.48)$
\end{tabular}

\section{Discussion}

TBM is the most dangerous form of primary tuberculosis complications ${ }^{1}$ with high morbidity, mortality and poor prognosis. ${ }^{1,4}$ In the United States, TBM was the most common form of extrapulmonary tuberculosis in 1997, Center for Disease Control (CDC) had reported that TBM accounted for 5.2\% of all cases of exclusively extrapulmonary disease and $0.7 \%$ of all reported cases of tuberculosis. The developing country has 1.3 million cases of tuberculosis and 40,000 tuberculosis-related deaths annually among children younger than 15 years. TBM is found in approximately 1 of every 300 untreated primary tuberculosis. ${ }^{2}$

TBM affects all ages especially in the first five years of life. It is uncommon in children younger than 6 months and almost unusual in infants younger than 3 months. $1,2,15$ The natural history of tuberculous infection can explain the incidence of TBM in this age. TBM occurs 6-12 months after primary infection and in $75 \%$ of cases, after 6 months of primary infection. ${ }^{16}$ In this study, we did not find any patients younger than 6 months old. Most children were younger than 5 years. The mean age of the TBM group was older than that of the primary tuberculosis group, but this difference was not statistically significance $(p=0.72)$.

History of contact with tuberculous adult is a contributing factor for diagnosing TBM and primary tuberculosis. 1,2,4 We found history of contact with tuberculous adult in $75 \%$ of TBM and $81 \%$ of primary tuberculosis patients. Kumar ${ }^{17}$ found history of contact in $42 \%$ of TBM patients, while Molavi ${ }^{15}$ found $20-30 \%$. Sanchez-Albisua had studied pulmonary tuberculosis during 2 decades (1978-1987 and 1988-1997) and they found that most of the source of infection in children was adult with tuberculosis, which accounted for $67.1 \%$ in the first decade and $58.3 \%$ in the second. 18
Willingham found history of contact in 30\% of patients with positive culture and hospital transmission was one of the source of infections. ${ }^{19}$ Saiman found that $24 \%$ of tuberculosis infections had history of contact. ${ }^{20}$ Martinez-Gonzales found 15 of 47 extra-pulmonary tuberculosis had history of contact, with $\mathrm{OR}=46.11$ (95\%CI 5.88;97.94 and $p<0.001) .{ }^{21}$ We found history of contact more than that of the previous studies, which showed the high prevalence of tuberculosis infection in Medan. International report from $\mathrm{WHO}$ showed that Indonesia contributed the third most tuberculosis infections in the world after China and India. ${ }^{22}$

Nutritional status has role in TBM occurrence. Severe malnutrition leads to decline of immunologic responses. ${ }^{1}$ In protein and calorie malnutrition, there are atrophy in thymus and lymphoid tissue and decrease of lymphocyte cell responses. ${ }^{24}$ Thus, tuberculosis infection accompanied with severe malnutrition verifies the decrease of T-lymphocyte responses. In this study, the OR of TBM in severe malnutrition children was 2.33 (95\%CI 0.52;10.48), but it was not statistically significant $(p=0.26)$. Studies in India reported severe malnutrition in tuberculosis patients and there was a significant relationship between severe tuberculosis and severe malnutrition. ${ }^{23}$ Unfortunately, our study did not show any roles of nutritional status in the occurrence of TBM, maybe because of the small number of subjects in this study.

There is a relationship between TBM and BCG vaccination status. The efficacy of $B C G$ vaccination to prevent TBM in this study was 0.8. A study in Thailand revealed that the efficacy of BCG to prevent TBM was 0.64 (95\%CI 0.3;0.82) and for all tuberculosis infections, was 0.74 (95\%CI 0.62;0.83), ${ }^{5}$ while in Sao Paulo were $84.5 \%$ and $80.2 \%$, respectively. ${ }^{25}$ A study reported that the efficacy of BCG vaccination to prevent severe extra-pulmonary tuberculosis was $0.78(95 \% \mathrm{CI} 0.46 ; 0.91)$ with $\mathrm{OR}=0.22(95 \% \mathrm{CI}$ $0.09 ; 0.54) .{ }^{21}$ Our study and previous studies showed that the efficacy of BCG vaccination in preventing TBM was more than $70 \%$. BCG vaccination aims to transform a virulence to non-virulence infections, but the cellular immunity activation still occurs. ${ }^{26}$ Tuberculosis infection in BCG vaccinated children leads to proliferation, differentiation, and activation of macrophage as well as cytokine released by memory $\mathrm{T}$ lymphocyte. ${ }^{27}$ Cytokines improve macrophages ability in killing M. tuberculosis. Cytokines can inhibit 
Nofareni, $M D$ et al: BCG vaccination, severe malnutrition, and tuberculous meningitis

bacterial growth and macrophage immobilization. Thus, hematogenous spread can be prevented. ${ }^{26}$

Four of sixteen TBM patients in this study had been BCG vaccinated, but they still suffered from TBM. This might occur because BCG vaccination has role especially in preventing hematogenous spread, but not for locally lymphogenous and direct spreads. Some other factors that influence the occurrence of TBM include nutritional status, age at onset of infection, and socioeconomic status. Tuberculosis infection in older age and improved nutritional status can decrease the risk of TBM. A study in India concluded that BCG vaccination was useful to prevent severe tuberculosis in children with good socioeconomic and nutritional status. ${ }^{23}$ Unfortunately, we did not have socioeconomic data of all patients.

As a conclusion, most TBM patients had not been $B C G$ vaccinated. Severe malnutrition did not influence the occurrence of TBM.

\section{References}

1. Suharso D, Hidayah SN. Meningitis tuberkulosa. In: Soetomenggolo TS, Ismael S, editors. Buku ajar neurologi anak. $1^{\text {st }}$ ed. Jakarta: Ikatan Dokter Anak Indonesia; 1999. p. 363-71.

2. Ramachandran TS. Tuberculosis meningitis. Medicine J 2002;7:1-33.

3. Tuberkulosis pada anak. In: Hasan R, Alatas H, editors. Buku kuliah ilmu kesehatan anak 2. Jakarta: Bagian Ilmu Kesehatan Anak Fakultas Kedokteran Indonesia; 2000. p. 573-91.

4. Inselman LS, Kendig EL, Tuberculosis. In: Chernick V, Kendig EL, editors. Kendig's disorders of the respiratory tract in children. $5^{\text {th }}$ ed. Philadelphia: Saunders; 1990. p. 760-6.

5. Padungchan S, Konjanat S, Kasiratta S, Daramas S, Ten Dam HG. The effectiveness of BCG vaccination of the newborn against childhood tuberculosis in Bangkok. Bull WHO 1986;64:247-58.

6. Fine PEM. Variation in protection by BCG: implication of and for heterologous immunity. Lancet 1995;346:1339-45.

7. Putrali J, Sutrisna B, Rahayu N, Gunardi AS, Gunowiseso. Penelitian efektifitas vaksinasi BCG pada anak-anak di 8 rumah sakit di Jakarta. Medika 1982;10:779-82.
8. Anonym. Profil kesehatan Republik Indonesia tahun 1998. Jakarta: Departemen Kesehatan dan Kesejahteraan Sosial RI; 1999.

9. Rahajoe NN. Tata laksana tuberkulosis pada anak. Sari Pediatri 2001;1:24-35.

10. Starke JR, Munoz F. Tuberculosis. In: Behrman RE, Kliegman RM, Jenson HB, editors. Nelson textbook of pediatrics. $16^{\text {th }}$ ed. Philadelphia: Saunders; 2000. p. 885-97.

11. Musa DA. Keamanan dan indikasi kontra imunisasi pada anak. In: Tjokronegoro A, Utama H, editors. Strategi pemilihan dan penggunaan vaksin serta antibiotika dalam upaya antisipasi perubahan pola penyakit. Naskah lengkap PKB IKA XXXIX. Jakarta: Balai penerbit FKUI; 1997. p. 65-75.

12. Fine PEM, Ponninghaus JM, Mane N. The distribution and implications of BCG scars in Northern Malawi. Bull WHO 1989;67:35-42.

13. Bloch $A B$. Screening for tuberculosis and tuberculosis infection in high risk populations. In. Fishman AP, Elias OA, Fishman JA, Grippi MA, Kaiser LR, Senior RM, editors. Fishman's pulmonary diseases and disorders volume 2. $3^{\text {rd }}$ ed. New York: McGraw-Hill; 1998. p. 2473-80.

14. Anonym. Baku rujukan antropometri, klasifikasi status gizi dan batas ambangnya. Rekomendasi Semiloka Antropometri di Indonesia; 1991 Feb 3-7; Ciloto, Indonesia.

15. Molavi A, Le Frock JL. Tuberculous meningitis. Med Clin North Am 1985;69:315-31.

16. Weil ML, Levin M. Infections of the nervous system. In: Menkes JH, editor. Textbook of child neurology. $5^{\text {th }}$ ed. Baltimore: Williams and Wilkins; 1995. p. 401-5.

17. Kumar R, Singh SN, Kohli N. A diagnostic rule for tuberculous meningitis. Arch Dis Child 1999;1:221-4.

18. Sanchez-Albisua I, Baquero-Artgao F, Castillo FD, Borque C, Garcia-Miguel MJ, Vidal ML. Twenty years of pulmonary tuberculosis in children: what has changed? Pediatr Infect Dis J 2002;21:49-53.

19. Willingham FF, Schmitz TL, Contreras M, Kalangi SE, Vivar M, Caviedes L, et al. Hospital control and multidrug-resistant pulmonary tuberculosis in female patients, Lima Peru. Emerg Infect Dis 2001;7:123-7.

20. Saiman L, Gabriel PS, Schulte J, Vargas MP, Kenyon T, Onorato I. Risk factors for latent tuberculosis infection among children in New York City. Pediatrics 2001;107:999-1003. 


\section{Paediatrica Indonesiana}

21. Martinez-Gonzales MTG, Castellanos JLV, Meza FAG. Effectiveness of the BCG vaccine to prevent severe extra-pulmonary tuberculosis in children. Int Pediatrics 2002;17:110-4.

22. Aditama TY. Tuberkulosis: diagnosis, terapi dan masalahnya. $4^{\text {th }}$ ed. Jakarta: Yayasan Penerbit Ikatan Dokter Indonesia; 2002. p. 131

23. Bai SS, Devi RL. Clinical spectrum of tuberculosis in BCG vaccinated children. Indian Pediatrics 2002;39:458-62.

24. Baratawijaya KG. Imunologi dasar. $4^{\text {th }}$ ed. Jakarta: Balai Penerbit FKUI: 2000; p. 220.
25. Filho VW, de Castilho EA, Rodrigues LC, Hittly SR. Effectiveness of BCG vaccination against tuberculous meningitis: a case-control study in Sao Paulo Brazil. Bull WHO 1990; 68:67-74.

26. Handojo RA, Liunanda S. Cell mediated immune response terhadap Mycobacterium tuberculosis dan kaitannya dengan penggunaan kemoterapi anti tuberkulose. Medika 1982;10:872-8.

27. Matondang CS. Aspek imunologi imunisasi. In: Ranuh IGN, Suyitno, Hadinegoro SRS, Kartasasmita C, editors. Buku imunisasi di Indonesia. $1^{\text {st }}$ ed. Jakarta: Satgas Imunisasi - IDAI; 2001. p. 5-11. 